TZCHNICAT THEORATCN CN BUILDING MATRIALS

FCR. USE IIN THE DESIGIN OF LON-COST HOUSIITG

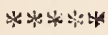

THE NATIONAT BURAUU OF STANDARDS

UIITED STADES DEPAEMIENT OP COLPHARE TASHINGECN, D. C.

\title{
$\operatorname{Sarch} 20,1230$.
}

\section{THEPMAI IISUIATION}

Insulating Values of Fuermal Irsulating Materials, Buileinm Motorials ano Basic Woll Units

This is a brief orosentation of therme I insiating values of commercial themal insulations, brilaing materials anà basic wall units, based on tests concucted bu the National Burcau of Stancircis, and. prese:tec in detail in Bureau of Starciarcs former Letter Circular Ijo. 227 (April 19, 1927), "Themal Insulation"; and Bureau of Stoncinos Roserrch Paje: Io. 291 (Ausut 6, 1930), "Heat Transfer Throgh Builaing Valls"; by M. Var Dusen and. J. I. Finci.

In ajoition to roviaing bases for calculatirg thermal insulating values of comonent parts of various tyos of building valls, the cata also prnvicies bases for comutins insulating values or resistances to transfer of heat by concuction, convection, ano raaiation through comolete Walls from surface to surfrce, i.e., from outsice air on one surface to insice air on the oposite surface. Tetal insulating value of a vall, incluoine total resistance of the two surfaces, calculated from air to air may be taizen as 1 plus the insulating value from surface to surface (a reasonably soo. average value for ordiury temperatures anu air velocities).

lout of print.

2out of print and not available by purchase but may be consulted in Government dejository libraries. 
! . 


\section{TAEIII}

Averae Insulating Values of Insulatin Mnterials*

\begin{tabular}{|c|c|c|c|c|}
\hline Trpes af Insulation & $: \frac{\text { Tapes }}{1}$ & 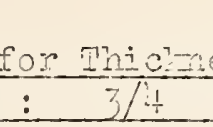 & $\frac{\text { SS Stated }}{\therefore \quad 1}$ & $\frac{\text { in Inches }}{: 35 / 5 * \%}$ \\
\hline $\begin{array}{l}\text { Fills (looso matcrials) } \\
\text { Flexible Insulation (quilts, } \\
\text { blantets or bats) } \\
\text { Rioid Insulation Bnards }\end{array}$ & $\begin{array}{l}: \\
: 1.73^{* * *} \\
\vdots 1.85 \\
: 1.52\end{array}$ & $\begin{array}{l}: \\
: 2.59 * * * \\
\vdots \\
: 2.78 \\
: 2.27 \\
:\end{array}$ & $\begin{array}{l}: 3.45 * * * \\
: 3.70 \\
: 3.03\end{array}$ & $\begin{array}{l}: 12.50 \\
: \\
: 13.40 \\
: 11.00 * * * \\
:\end{array}$ \\
\hline
\end{tabular}

TABITII

Insulatior Values af Builän Waterials and Basic Wall Units*

\begin{tabular}{|c|c|}
\hline Description of Material ñ Unit & $\begin{array}{l}\text { : Insulating Values } \\
: \text { for Matericil or } \\
\therefore \text { Init Describea }\end{array}$ \\
\hline 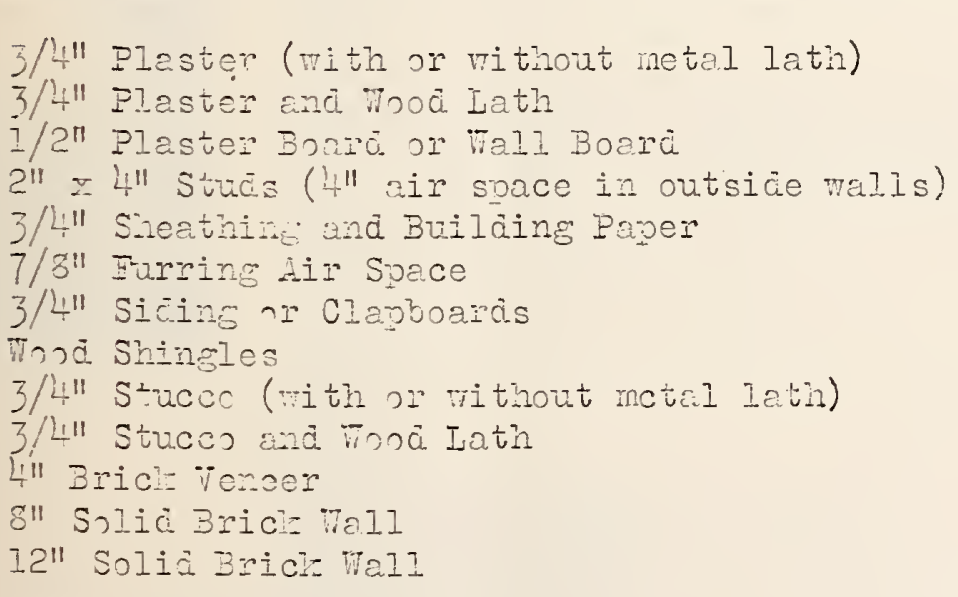 & $\begin{array}{l}0.33 \\
0.52 \\
0.38 \\
1.09 \\
0.75 \\
1.03 \\
1.10 \\
1.41 \\
0.20 \\
0.50 \\
0.52 \\
1.04 \\
1.56\end{array}$ \\
\hline
\end{tabular}

*Insulating values are expressea in tems of hours resistance, per cegreo Fanewheit, to the passage of I Btu of heat throuch 1 square foot of matcial per thichress givon or basic unit doscribed.

* Depth of air soace between 2" x $4 "$ stucs (wall thicle) usuraly fillea with loose or flexible insulation when such insulation is usco.

*** Insulating valucs for $1 / 2 ", 3 / 4 "$ and $1 "$ fills; ana $35 / 8 "$ af rigid insulation boards are given for comparative vurposes only, as materials of such thichess novla not ordinarily bc used in concral pracilice. 
